\title{
Geospatial tool-based morphometric analysis using SRTM data in Sarabanga Watershed, Cauvery River, Salem district, Tamil Nadu, India
}

\author{
P. Arulbalaji ${ }^{1}$ B. Gurugnanam ${ }^{1}$
}

Received: 21 September 2016/Accepted: 30 January 2017/Published online: 24 February 2017

(c) The Author(s) 2017. This article is published with open access at Springerlink.com

\begin{abstract}
A morphometric analysis of Sarabanga watershed in Salem district has been chosen for the present study. Geospatial tools, such as remote sensing and GIS, are utilized for the extraction of river basin and its drainage networks. The Shuttle Radar Topographic Mission (SRTM$30 \mathrm{~m}$ resolution) data have been used for morphometric analysis and evaluating various morphometric parameters. The morphometric parameters of Sarabanga watershed have been analyzed and evaluated by pioneer methods, such as Horton and Strahler. The dendritic type of drainage pattern is draining the Sarabanga watershed, which indicates that lithology and gentle slope category is controlling the study area. The Sarabanga watershed is covered an area of $1208 \mathrm{~km}^{2}$. The slope of the watershed is various from 10 to $40 \%$ and which is controlled by lithology of the watershed. The bifurcation ratio ranges from 3 to 4.66 indicating the influence of geological structure and suffered more structural disturbances. The form factor indicates elongated shape of the study area. The total stream length and area of watershed indicate that mean annual rainfall runoff is relatively moderate. The basin relief expressed that watershed has relatively high denudation rates. The drainage density of the watershed is low indicating that infiltration is more dominant. The ruggedness number shows the peak discharges that are likely to be relatively higher. The present study is very useful to plan the watershed management.
\end{abstract}

Keywords Drainage $\cdot$ Linear $\cdot$ Aerial $\cdot$ Relief and watershed

\section{P. Arulbalaji \\ arulbalajigeo@gmail.com}

1 Centre for Applied Geology, Gandhirgram Rural InstituteDeemed University, Dindigul, Tamil Nadu 624 302, India

\section{Introduction}

Morphometric analysis is defined as the capacity and mathematical analysis of the shape of the Earth's surface and dimension of its landforms (Pande and Moharir 2015; Kumar et al. 2015). Indian continental drainage and morphometric features of many river basins and watershed have been studied by conservative methods. Morphometric research is a quantitative technique for analyzing the land surface features. The detailed study of watershed supports and its proper management, allowing the individualization of its characteristics and evolving the best practices for the conservation of the assets that are within its territory (Banerjee et al. 2015; Vieceli et al. 2015). Water management studies are important for protecting the limited water resources, because at most of the places, surface water resources are rare, and at some places, it is totally absent (Sreedevi et al. 2009). Watershed management requires physiographic information, such as watershed slope, configuration of channel network, location of drainage divide, channel length, and geomorphologic parameters viz. relative relief, shape factor, circulatory ratio, bifurcation ratio, and drainage density for watershed prioritization and implementation of soil and water conservation measures (Sreedevi et al. 2013). The present scenario, researchers are used automatic terrain analyses based on an SRTM-DEM for geomorphological research. A more number of current studies are highlighting the importance of SRTM- DEM resolution on terrain, landscape, and soil analysis (Ehsani et al. 2010). The geographical information system (GIS) is helpful to use SRTM-DEM for extracting watershed and its drainage network by automatic methods. These types of techniques are an accurate with both quality and quantitative benefits for evaluating morphometric analysis. According to (Rawat 
and Mishra 2016), geospatial technology, such as remote sensing, and GIS have proved to be efficient tools and extensively used in micro watershed related studies, and particularly, GIS techniques offer a powerful tool for analysis, management, and extraction of spatial information for better understanding. The present study has focused on Sarabanga watershed of Salem district with an aim to understand the watershed characteristics. The characteristics were demarcated using three types of morphological analysis, such as linear, aerial, and relief aspects. An attempt has been made in this present study to analyze the different morphometric parameters using SRTM-DEM data and GIS techniques.

\section{Study area}

The Sarabanga River is an important tributary of the river Cauvery. The total geographical area of the watershed is $1208 \mathrm{~km}^{2}$. The study area geographically located between $11^{\circ} 28^{\prime} \mathrm{N}$ and $11^{\circ} 60^{\prime} \mathrm{N}$ latitudes, $77^{\circ} 45^{\prime} \mathrm{E}$ and $78^{\circ} 15^{\prime} \mathrm{E}$ longitudes. The elevation ranges various from 166 to $1635 \mathrm{~m}$, and the study area is situated in western part of Salem district in Tamil Nadu, India. The climate of the watershed is tropical particularly, the hot climate starts from March to May and cools down from June to December. The study area is geologically comprised by fissile hornblende biotite gneiss (Arulbalaji and Gurugnanam 2016a) and geomorphologically covered by pediment pediplain complex. The Sarabanga watershed has good groundwater potential zone (Arulbalaji and Gurugnanam 2016b). The location map of the study is given in Fig. 1.

\section{Materials and methods}

The morphometric analysis of the Sarabanga watershed has been prepared based on published Survey of India $(1: 50,000)$ toposheets and SRTM- DEM data. SRTMDEM (30 m spatial resolution) data were collected from USGS website. The SRTM has created an unparalleled data set of global elevations that is freely available for modelling and environmental applications (Sreedevi et al. 2009). The Arc GIS 10.2 software was used for achieving the automated extraction of watershed and drainage network. The watershed tool in hydrology toolbox of the Arc GIS 10.2 software has been used to delineate the boundary of the Sarabanga watershed. The delineated drainage networks were verified with Survey of India $(1: 50,000)$ toposheets. The drainage orders have been calculated based on Strahler and Horton methods of stream orders. The morphometric parameters have been calculated using extracted drainage network. The calculated parameters of Sarabanga watershed are given in three major heads, such as linear, aerial, and relief aspects. These three different aspects of morphometric characteristics were calculated by

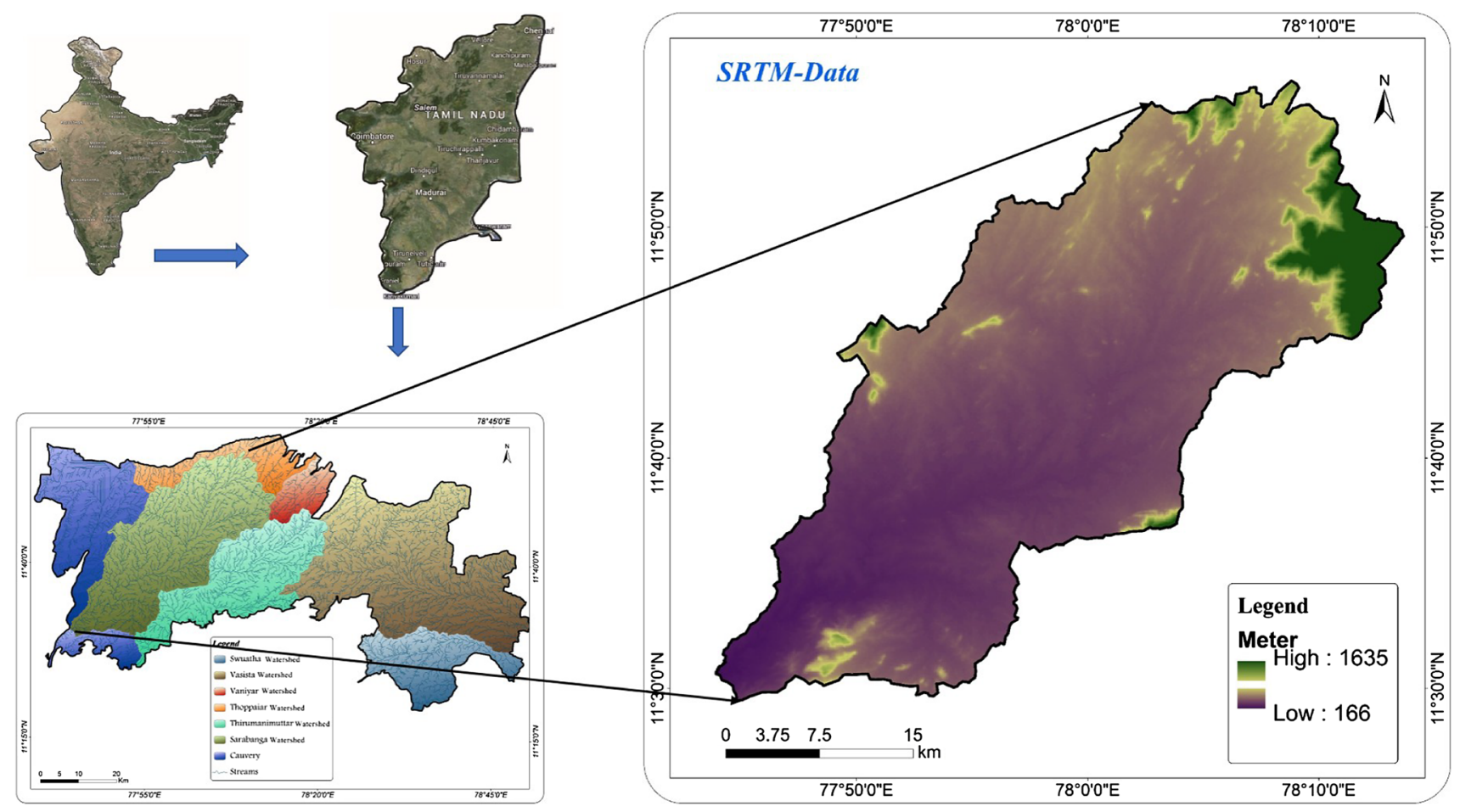

Fig. 1 Location map showing elevation range of the study area 
Table 1 Adopted methodology for computing morphometric parameters

\begin{tabular}{|c|c|c|c|c|}
\hline $\begin{array}{l}\text { S. } \\
\text { no }\end{array}$ & Parameters & Symbol & Formula & References \\
\hline \multicolumn{5}{|c|}{ 1. Linear aspects } \\
\hline 1.1 & Basin length & $L_{\mathrm{b}}$ & $L_{\mathrm{b}}=1.312 \times A^{0.568}$ & $\begin{array}{l}\text { Sreedevi et al. } \\
\text { (2005) }\end{array}$ \\
\hline 1.2 & Basin perimeter & $P$ & $P=$ outer boundary of drainage basin measured in kilometers & $\begin{array}{l}\text { Sreedevi et al. } \\
\quad(2005)\end{array}$ \\
\hline 1.3 & Stream order & $U$ & Hierarchical rank & Strahler (1964) \\
\hline 1.4 & Stream length & $L_{u}$ & Length of the stream in each order & Horton (1945) \\
\hline 1.5 & Mean stream length & $L_{\mathrm{sm}}$ & $\begin{array}{l}L_{\mathrm{sm}}=L_{u} / N_{u} \text {, where } L_{\mathrm{u}}=\text { total stream length of order ' } u \text { ', } N_{u}=\text { total no. of stream } \\
\text { segments of order ' } u \text { ' }\end{array}$ & Strahler (1964) \\
\hline 1.6 & Stream number & $N_{u}$ & No. of streams in each order & $\begin{array}{l}\text { Sreedevi et al. } \\
\quad(2013)\end{array}$ \\
\hline 1.7 & Stream length ratio & $R_{1}$ & $\begin{array}{l}R_{1}=L_{u} / L_{u-1} \text {, where } L_{u}=\text { the total stream length of the order ' } u \text { ' } L_{u-1}=\text { total stream } \\
\text { length of its next lower order }\end{array}$ & Horton (1945) \\
\hline 1.8 & Bifurcation ratio & $R_{\mathrm{b}}$ & $\begin{array}{l}R_{\mathrm{b}}=N_{u} / N_{u+1}, N_{u}=\text { total no. stream segments of order ' } u \text { ', } N_{u+1}=\text { number of } \\
\text { segments of the next higher order }\end{array}$ & Schumn (1956) \\
\hline 1.9 & $\begin{array}{l}\text { Mean bifurcation } \\
\quad \text { ratio }\left(R_{\mathrm{bm}}\right)\end{array}$ & $R_{\mathrm{bm}}$ & Average of bifurcation ratios of all orders & Strahler (1964) \\
\hline \multicolumn{5}{|c|}{ 2. Areal aspects } \\
\hline 2.1 & Drainage density & $D_{\mathrm{d}}$ & $D_{\mathrm{d}}=L_{u} / A$ where, $L_{u}=$ total stream length of all orders and $A=$ area of the basin $\left(\mathrm{km}^{2}\right)$ & Horton (1932) \\
\hline 2.2 & Drainage texture & $R_{\mathrm{t}}$ & $R_{\mathrm{t}}=N_{u} / P$, where $N_{u}=$ total no. of streams of all orders, $P=$ perimeter $(\mathrm{km})$ & Smith (1950) \\
\hline 2.3 & Stream frequency & $F_{\mathrm{s}}$ & $F_{\mathrm{s}}=N_{u} / A$, where $N_{u}=$ total no. of streams of all orders, $A=$ area of the basin $\left(\mathrm{km}^{2}\right)$ & Horton (1945) \\
\hline 2.4 & Elongation ratio & $R_{\mathrm{e}}$ & $R_{\mathrm{e}}=2 / L_{\mathrm{b}} \times(A / \pi)^{0.5}$ where $A=$ area of the basin, $L_{\mathrm{b}}=$ basin length $(\mathrm{km})$ & Schumm (1956) \\
\hline 2.5 & Circulatory ratio & $R_{\mathrm{c}}$ & $\begin{array}{l}R_{\mathrm{c}}=4 \times \pi \times A / P^{2}, \text { where } \pi=3.14, A=\text { area of the basin, } P^{2}=\text { square of the } \\
\text { perimeter }(\mathrm{km})\end{array}$ & Strahler (1956) \\
\hline 2.6 & Form factor & $R_{\mathrm{f}}$ & $R_{\mathrm{f}}=A / L_{\mathrm{b}}^{2}$, where $A=$ area of the basin $\left(\mathrm{km}^{2}\right), L_{\mathrm{b}}^{2}=$ square of basin length & Horton (1945) \\
\hline 2.7 & Infiltration number & $I_{\mathrm{f}}$ & $I_{\mathrm{f}}=D_{\mathrm{d}} \times F_{\mathrm{s}}$ where $D_{\mathrm{d}}=$ drainage density and $F_{\mathrm{s}}=$ drainage frequency & Umrikar (2016) \\
\hline \multicolumn{5}{|c|}{ 3. Relief aspects } \\
\hline 3.1 & Basin relief & $B_{\mathrm{h}}$ & Vertical distance between the lowest and highest points of basin & Schumm (1956) \\
\hline 3.2 & Relief ratio & $\left(R_{\mathrm{h}}\right)$ & $R_{\mathrm{h}}=B_{\mathrm{h}} / L_{\mathrm{b}}$, where $L_{\mathrm{b}}=$ basin length & Schumm (1956) \\
\hline 3.3 & Ruggedness number & $\left(R_{\mathrm{n}}\right)$ & $R_{\mathrm{n}}=B_{\mathrm{h}} \times D_{\mathrm{d}}$ where $B_{\mathrm{h}}=$ basin relief, $D_{\mathrm{d}}=$ drainage density & Strahler (1964) \\
\hline
\end{tabular}

the following formula (Table 1). The slope map, aspect map, and topographic anomalies were delineated from SRTM-DEM data using slope, aspect, and profile tools, respectively, in the ArcGIS 10.2 software.

\section{Slope}

Slope analysis is an essential parameter in morphometric studies (Sreedevi et al. 2009). The slope map was prepared from SRTM-DEM data using the ArcGIS 10.2 software (Fig. 2). The results of slope were delineated into five categories with equal interval, such as $<10^{\circ}$, $10-20^{\circ}, 20-30^{\circ}, 30-40^{\circ}$, and $>40^{\circ}$. The below $10^{\circ}$ of slope were dominantly found in the study area, and $30^{\circ}-$ $40^{\circ}$ and above $40^{\circ}$ categories were occurred in northeastern part of the study area. In general, the variations of slope in the study area are controlled by the local lithological settings.

\section{Topographic anomalies}

The topographic anomalies were calculated from SRTM data using profiling methods in the ArcGIS 10.2 software. The range of elevation in the study area differs from 166 to $1635 \mathrm{~m}$. Topographic anomalies were delineated in five different sites, such as A-B, C-D, E-F, G-H, and I-J profile (Fig. 3). The profile maps are illustrating the shape of the terrain in the study area.

\section{Result and discussion}

The morphometric structures of the Sarabanaga watershed have been examined, and the results are discussed in the following. The general drainage pattern of Sarabanga watershed is dendritic (Fig. 4). It is characterized by irregular branching of tributary streams in many directions 
Fig. 2 Slope map of Sarabanga watershed



joining the main channel (Sreedevi et al. 2009). The morphometric analysis is carried out by linear aspects, aerial aspects, and relief aspects (Table 2).

\section{Linear aspect}

The linear aspects parameters were considered about stream order $(U)$, stream numbers $\left(N_{u}\right)$, stream length $\left(L_{u}\right)$, mean stream length $\left(L_{\mathrm{sm}}\right)$, stream length ratio $\left(R_{1}\right)$, and bifurcation ratio $\left(R_{\mathrm{b}}\right)$.

\section{Stream order $(U)$}

The concept of stream order has been introduced by Horton (1932) (Pande and Moharir 2015). The stream order is the first step in drainage basin, which is based on the hierarchic ranking of streams and determines the stream orders. Stream classification of a river basin is derived from stream ordering method. Strahler (1964) method of stream classification was carried out in this study. According to Strahler (1964) method, two first-order streams join and form the channel segment of order 2. Where two 2-order stream join, the channel segment of order 3 formed, likewise stream orders are increasing. The highest order of stream is the trunk stream of the basin. According to Strahler (1964), the watershed has been designated as the sixth-order basin. In the present study, high frequency has been observed in the first-order streams (Table 2). Most of the first-order stream is observed in highly elevated region of the study area, which indicates the terrain density and compressed nature of the basic lithology. The occurrence of large number of the streams in the watershed indicates that the topography is still suffering erosion and at the less number indicates developed topography (Pande and Moharir 2015).

\section{Stream length $\left(L_{u}\right)$}

The length of the streams was calculated according to Horton law with the help of GIS tool. Stream length is the vital hydrological character of the basin as it reveals surface runoff characteristics. Usually, the total length of stream segments is high in first-order stream and decreases in stream order increases (Waikar and Nilawar 2014). The total stream length of the study area is 1622 and I, II, III, IV, V, and VI-order total stream length is 808, 377, 272, 74,34 , and 57, respectively. In general, the larger slope and fine texture of topography have relatively smaller length of stream. The stream of relatively longer lengths of streams generally indicates the flatter gradient. The first-order stream length is $<50 \%$ in the study area, which means that the first-order streams were controlled by the slope and topography of the basins. 



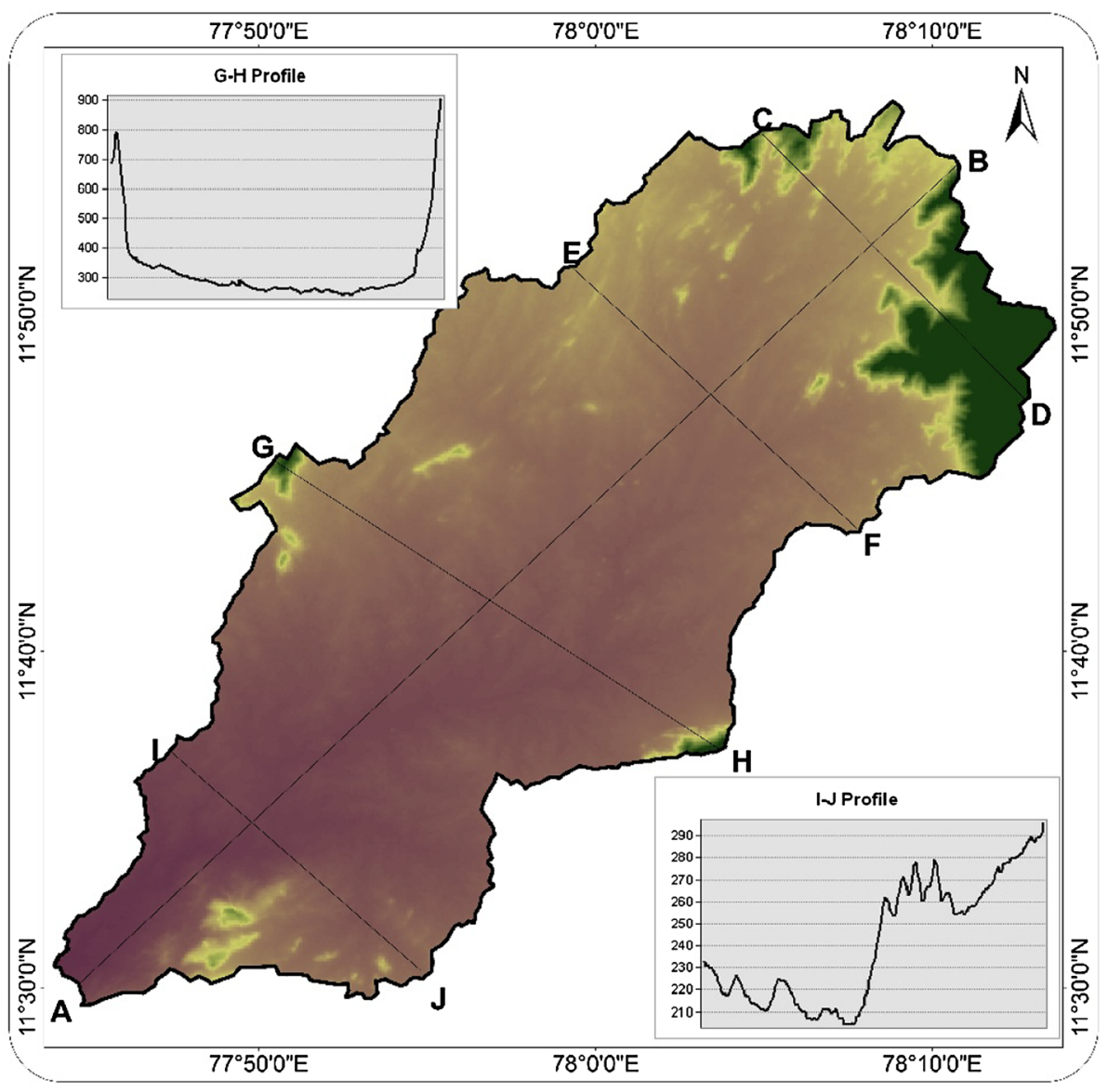

Fig. 3 Topographic anomalies of Sarabanga watershed

\section{Mean stream length $\left(L_{s m}\right)$}

The mean stream length is a property related to the drainage networks and its associated surfaces. The mean stream lengths were calculated using the formula of total stream length of order divided by total number of stream segments of order. The mean stream length is higher in less stream order, and lesser in high stream order is due to variations in slope and topography. The mean stream length is $1622 \mathrm{~km}$ in the study area. The mean stream length is directly related to mean annual runoff; therefore, the highest mean stream length has relatively high mean annual rainfall runoff and relatively low mean annual rainfall runoff in less mean stream length. In the present study, mean stream length is indicating the high mean annual rainfall runoff.

\section{Stream numbers $\left(N_{u}\right)$}

The total stream segments in a given order are defined as stream number. Stream number is directly proportional to size of the contributing basin and to channel dimensions (Hajam et al. 2013). According to the Horton's laws of stream number explained that the number of stream segments of each order form an inverse geometric sequence with plotted against order, which means that the number of streams usually decreases in geometric progression as the stream order increases (Rao et al. 2010; Sreedevi et al. 2013; Pande and Moharir 2015). The higher number of streams indicates the impermeability nature and infiltration. Using GIS application, the total number of streams of each order was computed. The total number of streams in Sarabanga watershed is 1110 . Whereas I, II, III, IV, V, and VI-order total stream is $857,184,52,13,3$, and 1 , respectively. It reveals that the study area has relatively greater percentage of the first-order streams $(>70 \%)$ and there is a possibility of unpredicted flood during heavy rainfall (Chitra et al. 2011).

\section{Stream length ratio $\left(R_{l}\right)$}

Stream length ratio has an important link with surface flow and discharge and erosion stage of the basin. Stream length ratio is defined as the ratio of the mean length of one order to the next lower order of the stream segments. The ratio between the streams of different orders shows the changes 
Fig. 4 Drainage ordering map of Sarabanga watershed

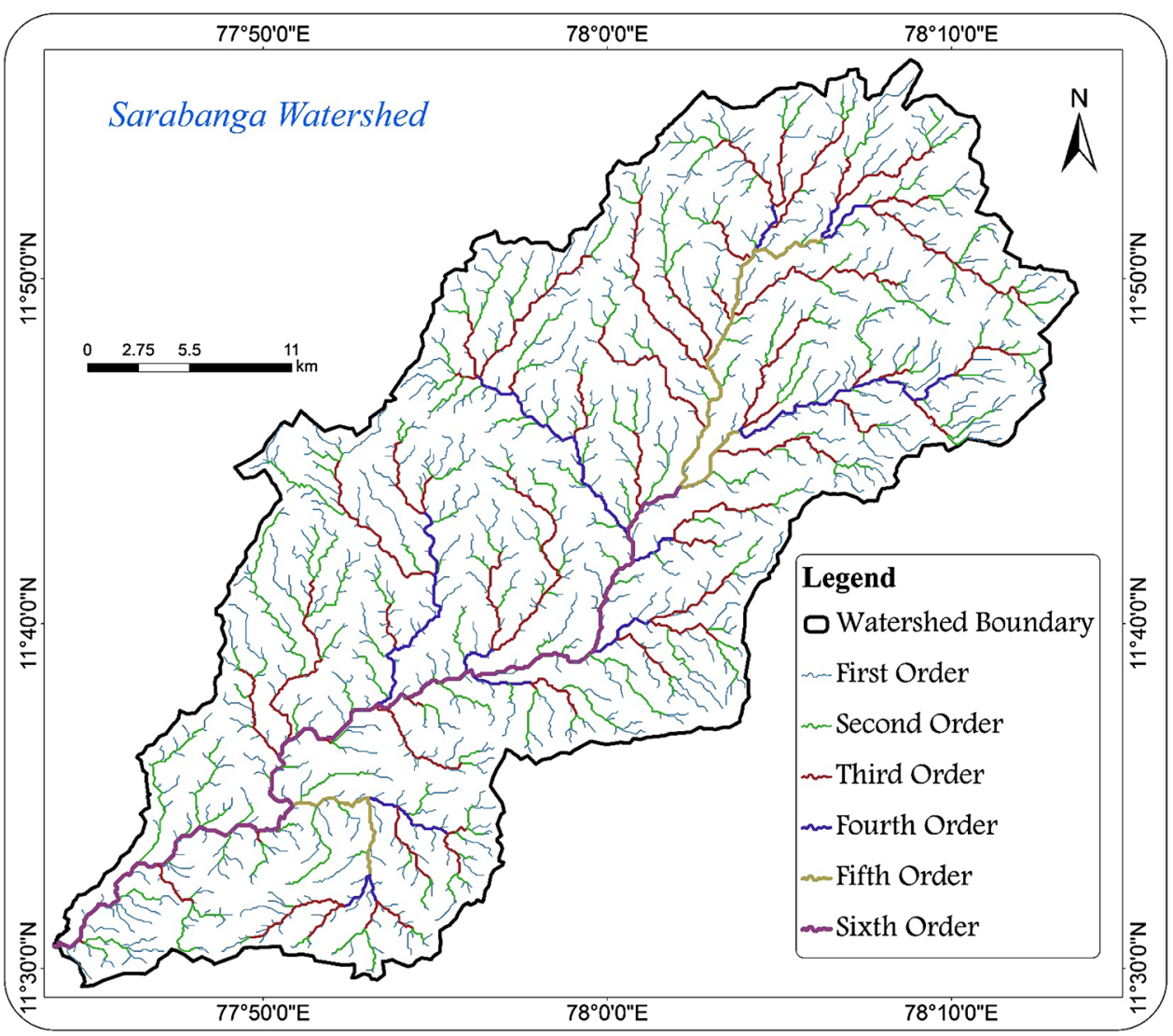

in basin, which may be the variation in slope and topography and the stream length ratio changes from one order to another order indicates their late youth stage of geomorphic development (Pande and Moharir 2015). The length ratio value ranges from 0.27 to 1.68 . The higher values were noticed in the fifth stream orders and lower values noticed in the third stream orders.

\section{Bifurcation ratio $\left(R_{b}\right)$}

According to Strahler 1964, the term Bifurcation ratio is defined as the ratio of the number of streams of given order to the number of streams in the next higher order. $R_{\mathrm{b}}$ is depending upon the physiography, slope, and climatic conditions. Bifurcation ratio has a relationship with the branching pattern of a drainage network. The relatively high bifurcation ratio indicates early hydrograph peak with a potential for flash flooding during the storm events and the relatively lower value of mean bifurcation ratio also proposes the geological heterogeneity, higher permeability, and lesser structural control in the basin (Hajam et al. 2013). Strahler (1964) and Schumm (1956) has stated that bifurcation ratio value between 3 and 5 in basins that were geologic structures does not exercise a dominant influence on the drainage pattern. The higher values indicate the influence of geological structure on the drainage pattern and suffered more structural disturbances. The study area bifurcation ratio ranges from 3 to 4.66, and the mean bifurcation ratio is 3.898 . Therefore, the geologic structures do not play a vital role in the study area.

\section{Areal aspect}

The areal aspect parameters were considered about drainage density, stream frequency, drainage texture, infiltration number, form factor ratio, elongation ratio, circularity ratio, and length of overland flow. Area of a basin and perimeter is the main parameters in quantitative morphology.

\section{Area $(A)$ and perimeter $(P)$}

Area of the basin is calculated as total area projected upon a horizontal plane contributing to accumulate of all order of basins. Perimeter is the length of the basin boundary (Ahmed et al. 2010). Basin area is hydrologically important because which is directly affects the size of the storm hydrograph and the magnitudes of peak and mean runoff (Rao et al. 2010). Area of the basin has a strong relationship with mean annual runoff. The Sarabanga watershed covers an area of $1208 \mathrm{~km}^{2}$ and the perimeter is $205 \mathrm{~km}$. 
Table 2 Morphometric results of Sarabanga Watershed

\begin{tabular}{|c|c|c|c|c|c|c|c|}
\hline $\begin{array}{l}\text { S. } \\
\text { no }\end{array}$ & \multirow{2}{*}{$\begin{array}{l}\text { Parameters } \\
\text { Area }\end{array}$} & \multicolumn{6}{|c|}{ Results } \\
\hline 1. & & \multicolumn{6}{|c|}{$1208 \mathrm{~km}^{2}$} \\
\hline 2. & Basin length & \multicolumn{6}{|c|}{$73 \mathrm{~km}$} \\
\hline 3. & Perimeter & \multicolumn{6}{|c|}{$205 \mathrm{~km}$} \\
\hline 4. & Stream order & \multicolumn{6}{|l|}{6} \\
\hline \multirow[t]{2}{*}{5.} & \multirow{2}{*}{$\begin{array}{l}\text { No. of streams in each } \\
\quad \text { order }\left(N_{u}\right)\end{array}$} & I & II & III & IV & $\mathrm{V}$ & VI \\
\hline & & 857 & 184 & 52 & 13 & 3 & 1 \\
\hline 6. & $\begin{array}{l}\text { Total number of streams } \\
\text { in all orders }\end{array}$ & \multicolumn{6}{|l|}{1110} \\
\hline 7. & $\begin{array}{l}\text { Stream length in each } \\
\quad \text { order }(\mathrm{km})\left(L_{u}\right)\end{array}$ & 808 & 377 & 272 & 74 & 34 & 57 \\
\hline 8. & $\begin{array}{l}\text { Total length of streams of } \\
\text { all orders }\end{array}$ & 1622 & & & & & \\
\hline 9. & Mean stream length $\left(L_{\mathrm{sm}}\right)$ & 0.94 & 2.05 & 5.23 & 5.7 & 11.33 & 57 \\
\hline 10. & Stream length ratio $\left(R_{1}\right)$ & 0.47 & 0.72 & 0.27 & 0.46 & 1.68 & - \\
\hline \multirow[t]{2}{*}{11.} & Bifurcation ratio $\left(R_{\mathrm{b}}\right)$ & I/II & II/III & III/ & IV/ & V/VI & $\mathrm{I} / \mathrm{II}$ \\
\hline & & 4.66 & 3.5 & 4 & 4.33 & 3 & 4.6 \\
\hline 12. & $\begin{array}{l}\text { Mean bifurcation ratio } \\
\quad\left(R_{\mathrm{bm}}\right)\end{array}$ & \multicolumn{6}{|c|}{3.898} \\
\hline 13. & $M_{\mathrm{x} \text {-rel }}-M_{\mathrm{n} \text {-rel }}$ & \multicolumn{6}{|c|}{$1635-166=1469$} \\
\hline 14. & $\begin{array}{l}\text { Drainage density } \\
\text { (D) }\left(\mathrm{km} / \mathrm{km}^{2}\right)\end{array}$ & \multicolumn{6}{|l|}{1.34} \\
\hline 15. & Drainage texture $\left(R_{\mathrm{t}}\right)$ & \multicolumn{6}{|c|}{5.415} \\
\hline 16. & Stream frequency $\left(F_{\mathrm{s}}\right)$ & \multicolumn{6}{|l|}{0.92} \\
\hline 17. & Elongation ratio $\left(R_{\mathrm{e}}\right)$ & \multicolumn{6}{|l|}{0.54} \\
\hline 18. & Circularity ratio $\left(R_{\mathrm{c}}\right)$ & \multicolumn{6}{|c|}{0.364} \\
\hline 19. & Form factor $\left(R_{\mathrm{f}}\right)$ & \multicolumn{6}{|l|}{0.23} \\
\hline 20. & Infiltration number & \multicolumn{6}{|c|}{1.2328} \\
\hline 21. & Total relief $\left(h_{\mathrm{m}}\right)$ & \multicolumn{6}{|c|}{$1469 \mathrm{~m}, 1.469 \mathrm{~km}$} \\
\hline 22. & Relief ratio $\left(R_{\mathrm{h}}\right)$ & \multicolumn{6}{|c|}{0.0201} \\
\hline 23. & Ruggedness number $\left(R_{\mathrm{n}}\right)$ & \multicolumn{6}{|l|}{1.96} \\
\hline
\end{tabular}

\section{Drainage density $\left(D_{d}\right)$}

Drainage density is introduced by Horton (1932) in American hydrologic literature which is an expression to indicate the closeness of spacing of channels (Ahmed et al. 2010). The drainage density is calculated as the total length of streams of all the orders as per the drainage area. Drainage density is the one of the dominant character of landform element which provides a numerical measurement of landscape and runoff potential. Drainage density depends upon the climate, type of rocks, relief, infiltration capacity, vegetation cover, surface roughness, and run-off intensity index. Low drainage density indicates the highly resistant or permeable subsoil material, dense vegetation, and low relief. High drainage density indicates weak or impermeable subsurface material, sparse vegetation and high relief. Low drainage density leads to coarse drainage texture, and high drainage density leads to fine drainage texture (Ahmed et al. 2010; Ramaiah et al. 2012). In general, the low drainage density occurs on granite, gneiss, and schist regions (Rao et al. 2010). A high drainage density leads a highly dissected drainage basin with a relatively rapid hydrological response to rainfall events, and low density leads a poorly drained basin with a slow hydrologic response (Hajam et al. 2013). In the present study, drainage density is $1.34 \mathrm{~km} / \mathrm{km}^{2}$. It is indicating low drainage density. Therefore, the Sarabanga water shed having high resistant or permeable subsoil, dense vegetative cover, and low relief (Ahmed et al. 2010).

\section{Drainage texture $\left(R_{t}\right)$}

Drainage texture depends upon the climate, rainfall, vegetation, underlying lithology, infiltration capacity, and relief aspects of the terrain (Sreedevi et al. 2013). Drainage texture is calculated as the total number of stream segments of all orders per perimeter of that area. Smith (1950) has classified the drainage texture based on drainage density into five different classes. The drainage density $<2$ indicates very coarse, between 2 and 4 is related to coarse, between 4 and 6 is moderate, between 6 and 8 is fine, and greater than 8 is very fine drainage texture. The drainage texture of the study area is 5.415. According to Smith (1950) classification, the study area is having a very coarse drainage texture.

\section{Stream frequency $\left(F_{s}\right)$}

The stream frequency is calculated as the total number of stream segments of all orders per unit area (Horton 1945). The stream frequency has a positive correlation with drainage density, the watershed indicating an increase in stream population with respect to increase in drainage density (Rao et al. 2010; Waikar and Nilawar 2014). In the study area, the stream frequency value is 0.92 . It is indicating low frequency. Low stream frequency values are susceptible to high erosion and sedimentation load (Sreedevi et al. 2013).

\section{Elongation ratio $\left(R_{e}\right)$}

Elongation ratio is the ratio between the diameter of the circle of the same area as the drainage basin and the maximum length of the basin (Schumm 1956). Usually, the elongation ratio is associated with high relief and steep ground slope. The $R_{\mathrm{e}}$ values are close to 1 typically very low relief, and values in 0.6-0.8 are associated with high relief and moderate to steep ground slop (Strahler 1964). The elongation ratio values can be grouped into three classes, namely, circular $(>0.9)$, oval $(0.9-0.8)$ and less 
elongated $(<0.7)$. In the study area, $R_{\mathrm{e}}$ value is 0.54 which means that the study area is less elongated.

\section{Circulatory ratio $\left(R_{c}\right)$}

The circulatory ratio is mainly focused on the length and frequency of streams, geological structures, land use/land cover, climate, relief, and slope of the basin (Das et al. 2012). The circulatory ratio is the ratio of the area of the basin to the area of a circle having the same circumference as the perimeter of the basin (Strahler 1964). $R_{\mathrm{c}}$ values approaching 1 indicate that the shapes of the basin are like circular (Sreedevi et al. 2013). The circulatory ratio of the study area is 0.364 .

\section{Form factor $\left(R_{f}\right)$}

According to Horton (1945), the form factor is defined as the ratio of basin area to square of the basin length. The form factor is indicating the flow intensity of a basin. The high form factor experiences larger peak flows of shorter duration, and low form factor experiences lower peak flows of longer duration (Waikar and Nilawar 2014). The form factor of the study area is 0.23 . The less value of form factor $<0.25$ indicates elongated sub-basins.

\section{Infiltration number $\left(I_{f}\right)$}

The infiltration number has been defined as the product of drainage density and drainage frequency, which gives an idea about the rate of infiltration and reveals impermeable bedrock and high relief areas in the watershed (Umrikar 2016). The low infiltration number indicates that runoff will be very low and the infiltration capacity very high and so on. In the present study, infiltration number is 1.23. Therefore, the runoff is relatively moderate.

\section{Relief aspect}

The relief aspects of the drainage basin analysis have relationship with the study of three-dimensional features involving area, volume, and altitude of vertical dimension of landforms to analyze different geo-hydrological characteristics (Hajam et al. 2013). The relief aspects parameters were considered as basin relief, relief ratio, and ruggedness number.

\section{Basin relief $(R)$}

Basin relief is an essential parameter to understand the geomorphic process and landform characteristics. The basin relief has been calculated as vertical distance between the lowest and highest points of the basin
(Sreedevi et al. 2009). The influence of relief is inextricably bound up with other basin characteristics and is of greater significance to some indices of basin response particularly peak run-off rates and sediment delivery than others. Basin relief is an index of the potential energy available in the drainage basin, and of course, the greater relief is the greater erosional forces acting on the basin. In the present study, lower relief $(166 \mathrm{~m})$ and higher relief $(1635 \mathrm{~m})$ are noticed. Therefore, relief of the watershed is $1469 \mathrm{~m}$. It is indicating that the erosional forces and the mean denudational rates are higher in the study area.

\section{Relief ratio $\left(R_{h}\right)$}

The relief ratio is defined as the ratio of maximum relief to horizontal distance along the longest dimension of the basin parallel to the principal drainage line (Schumm 1956). The relief ratio is generally increases with decreasing drainage area and size of the watershed in a given basin. There is a big correlation between hydrological characteristics and the relief ratio of the drainage basin (Ahmed et al. 2010). The highest value of relief ratio specifies steep slope and high relief, while the lower relief ratio specifies the low degrees of slope. The relief ratio of the study area is 0.02 . The relief ration value is very less, which indicates that the sediment loss per unit area is likely to be low.

\section{Ruggedness number}

According to Strahler 1968, ruggedness number is the product of relief of the basin and drainage density, where both parameters are in the same unit. An extreme high value of ruggedness number occurs when both variables are large and slope is steep (Umrikar 2016). In the present study, the ruggedness value is 1.96 . It is indicating that peak discharges are likely to be relatively higher.

\section{Conclusion}

The present investigation has proved that remote sensing and geographical information system techniques are more efficient for computation and analysis of the morphometric parameters. There are 19 morphometric parameters that were calculated with the help of the Arc GIS 10.2 software. These 19 parameters help to understand the terrain characteristics, such as surface runoff, infiltration capacity, topography, lithology, and hydrological properties of the study area. According to Strahler classification, the study area has the sixth-order watershed and the dendritic drainage pattern is observed. The results of form factor, circulatory ratio, and elongation ratio stated the elongated 
shape of the watershed. The bifurcation ratio and stream numbers of the watershed show vulnerability for unpredicted flood during heavy rainfall. The value of mean bifurcation ratio is indicating that the watershed is not affected by structural disturbances and geological structures. The low drainage density, stream frequency, and infiltration number indicate that the watershed is caused by permeable subsoil and runoff is relatively moderate. The low drainage density shows good dimensions to construct the water harvesting structures in the streams. The high basin relief, relief ratio, and ruggedness number reveal that the peak discharge is likely to be relatively higher and the sediment yield per unit area is low.

Morphometric analysis of Sarabanga watershed shares valuable evidences and results for planning watershed development activities of the area. The current scenario of Salem district becoming a dry area, this investigation and its attributes will be playing a vital role in watershed management and development of the study area.

Acknowledgements Author highly thankful to the Centre for applied Geology, Gandhigram Rural Institute-Deemed University for providing lab facilities to do this work.

Open Access This article is distributed under the terms of the Creative Commons Attribution 4.0 International License (http:// creativecommons.org/licenses/by/4.0/), which permits unrestricted use, distribution, and reproduction in any medium, provided you give appropriate credit to the original author(s) and the source, provide a link to the Creative Commons license, and indicate if changes were made.

\section{References}

Ahmed SA, Chandrashekarppa KN, Raj SK, Nischitha V, Kavitha G (2010) Evaluation of morphometric parameters derived from ASTER and SRTM DEM - a study on Bandihole Sub-watershed Basin in Karnataka. J Indian Soc Remote Sens 38:227-238

Arulbalaji P, Gurugnanam B (2016a) An integrated study to assess the groundwater potential zone using geospatial tool in Salem District. J Hydrogeol Hydrol Eng, South India. doi:10.4172/ 2325-9647.1000136

Arulbalaji P, Gurugnanam B (2016b) Groundwater quality assessment using geospatial and statistical tools in Salem District, Tamil Nadu, India. Appl Water Sci. doi:10.1007/s13201-016-0501-5

Banerjee A, Singh P, Pratap K (2015) Morphometric evaluation of Swarnrekha watershed, Madhya Pradesh, India: an integrated GIS-based approach. Appl Water Sci. doi:10.1007/s13201-0150354-3

Chitra C, Alaguraja P, Ganeshkumari K, Yuvaraj D, Manivel M (2011) Watershed characteristics of Kundah sub-basin using remote sensing and GIS techniques. Int $\mathrm{J}$ Geomat Geosci 2(1):311-335

Das A, Mondal M, Das B, Ghosh AR (2012) Analysis of drainage morphometry and watershed prioritization in Bandu Watershed, Purulia, West Bengal through remote sensing and GIS technology—a case study. Int J Geomat Geosci 2(4):995-1013
Ehsani AH, Qulel F, Maleklan A (2010) Effect of SRTM resolution on morphometric feature identification using neural network-self organizing map. Geoinformatica 14:405-424

Hajam RA, Hamid A, Bhat S (2013) Application of morphometric analysis for geo-hydrological studies using geo-spatial technology - a case study of Vishav Drainage Basin. Hydrol Curr Res. doi:10.4172/2157-7587.1000157

Horton RE (1932) Drainage basin characteristics. Trans Am Geophys Union 13:350-361

Horton RE (1945) Erosional development of stream and their drainage density: hydrophysical approach to quantitative geomorphology. Geol Soc Am Bull 56:275-370

Kumar A, Samuel SK, Vyas V (2015) Morphometric analysis of six sub-watersheds in the central zone of Narmada River. Arab J Geosci 8:5685-5712. doi:10.1007/s12517-014-1655-9

Pande CB, Moharir K (2015) GIS based quantitative morphometric analysis and its consequences: a case study from Shanur River Basin, Maharashtra India. Appl Water Sci. doi:10.1007/s13201015-0298-7

Ramaiah SN, Gopalakrishna GS, Vittala SS, Najeeb K (2012) Morphometric analysis of sub-basins in and around Malur Taluk, Kolar District, Karnataka using remote sensing and GIS techniques. Nat Environ Pollut Technol 11(1):89-94

Rao N, Latha S, Kumar A, Krishna H (2010) Morphometric analysis of Gostani River Basin in Andhra Pradesh State, India. Int J Geomat Geosci 1(2):179-187

Rawat KS, Mishra AK (2016) Evaluation of relief aspects morphometric parameters derived from different sources of DEMs and its effects over time of concentration of runoff $\left(T_{\mathrm{c}}\right)$. Earth Sci Inform 9:409-424

Schumm SA (1956) Evolution of drainage systems and slopes in Badlands at Perth Amboy, New Jersey. Bull Geol Soc Am 67:597-646

Smith KG (1950) Standards for grading texture of erosional topography. Am J Sci 248:655-668

Sreedevi PD, Subrahmanyam K, Shakeel A (2005) The significance of morphometric analysis for obtaining groundwater potential zones in a structurally controlled terrain. Environ Geol 47(3):412-420

Sreedevi PD, Owais S, Khan HH, Ahmed S (2009) Morphometric analysis of a watershed of South India using SRTM data and GIS. J Geol Soc India 73:543-552

Sreedevi PD, Sreekanth PD, Khan HH, Ahmed S (2013) Drainage morphometry and its influence on hydrology in a semi-arid region: using SRTM data and GIS. Environ Earth Sci 70:839-848

Strahler AN (1956) Quantitative slope analysis. Bull Geol Soc Am 67:571-596

Strahler AN (1964) Quantitative geomorphology of drainage basins and channel networks. In: Chow VT (ed) Handbook of applied hydrology. McGraw Hill, New York, pp 439-476

Strahler AN (1968) Quantitative geomorphology. In: Fairbridge RW (ed) Encyclopedia of geomorphology. Reinhold Book Crop, New York

Umrikar BN (2016) Morphometric analysis of Andhale watershed, Taluka Mulshi District Pune, India. Appl Water Sci. doi:10. 1007/s13201-016-0390-7

Vieceli N, Bortolin TA, Mendes LA, Bacarim G, Cemin G, Schneider VE (2015) Morphometric evaluation of watersheds in Caxias do Sul City, Brazil, using SRTM (DEM) data and GIS. Environ Earth Sci 73:5677-5685

Waikar ML, Nilawar AP (2014) Morphometric analysis of a drainage basin using geographical information system: a case study. Int $\mathrm{J}$ Multidiscip Curr Res 2:179-184 